\title{
Nutrition, public health, and the new nutrition science: Academic thought, professional action
}

This editorial is an attempt to encourage us to think about the balance between evidence and action in public health nutrition, so as to become much more effective as professionals working in the public interest. It is also about a theme that has been on my mind for some time now: the distinction between thinking as academic and acting as a professional.

The issues that confront us are awesome. Throughout the world malnutrition in the classic definition is receding only very slowly, if at all. And as I write, new official figures show that roughly a quarter of 11-15-year-old schoolchildren in England are clinically obese, a figure that has almost doubled in the last decade, which is described by Colin Waine of the UK National Obesity Forum as 'a public health timebomb' ${ }^{1}$. If this is war, we are not winning. Many would say we are losing. A theme of this editorial is that our weapons are ineffective.

\section{Past examples}

What we now call public health nutrition is as old as what we call civilisation. Sumerian records dating back 6000 years show that the rulers of the region, including the site of the Garden of Eden within what is now Iraq, were concerned about food security (as they should be now); and Egyptian records show that the Pharaohs understood that pyramid builders needed plenty of nourishing food ${ }^{2}$. The leaders of earlier societies with no written records will also have known what foods and drinks preserved the strength and health of their peoples.

Public health is now part of the modern scientific endeavour. From its beginnings, which can be dated back to the 17 th century in Europe ${ }^{3}$, public health policy and practice, making use of surveys and statistical methods, was concerned with the underlying and basic causes of disease, health and well-being, and with doing what is best for whole populations.

Public health has also always been all about balancing the need for evidence and the need for action. John Snow, a founder of modern epidemiology, drew careful maps of the incidence of cholera in different districts in London, checked and checked again; then decided that no more research was needed; and in the summer of 1854, without permission from the authorities, removed the handle of the Broad Street pump in what is now Broadwick Street in Soho. This direct action, decades before formulation of the germ theory of disease, proved to work ${ }^{4}$.
Urban water was supplied by private companies in those unenlightened days. John Snow's place in history is as one of the public health pioneers within industrialised Europe. These radical scientists pressed governments to identify water as a public good ${ }^{5}$, and to accept that its supply and safety, together with the building of closed sewers, must be the responsibility of the state.

But suppose that the authorities of the day had insisted, quite correctly, that John Snow's actions were anecdotal and had produced only limited evidence, and so no conclusion was possible? Suppose they had also insisted on replication of his intervention in several places, conducted by teams of investigators deemed (unlike him, of course) to be objective and disinterested? And suppose any commission of enquiry, and the mayors and aldermen in the cities in which such meticulous and scrupulous investigations using state-of-the-science methodology were to be conducted, included eminent personages who happened to be directors of private water companies or shareholders in these lucrative businesses? Would cholera and other water-borne diseases have been brought under control in London and other great cities quite so soon? It seems rather unlikely.

\section{Present and future challenges}

I think such stories from the past can tell us a lot about how we as a profession should think, work, and act now and in future. I am originally from Australia, a country of vast contrast between urban luxury and aboriginal misery. I am now settled in Britain but also travel and work in the South, including in India and Africa.

From where I sit in my office in Southampton, it seems pretty obvious what was needed in the 19th century to make London and the other newly industrialised cities of Europe, and then of North America, better places to live. This included the provision of clean and safe water, which meant separating water and faecal material; food and drink supplies that were adequate, uncontaminated and nutritious; universal basic sanitation, especially to protect the lives and health of mothers, infants and young children; and decent working conditions with adequate pay and time off to enjoy life.

But when I visit and work in unprivileged parts of the world in the South, it is all too apparent that some or even all of such basic provisions are often not made. Indeed, there is good evidence that the general state of public 
health, including nutrition, is deteriorating - most of all in those parts of the world where government is most disrupted, by famine, invasion, war, exploitation, corruption, unfair terms of trade and economic globalisation, and such-like phenomena that make the rich richer and the poor poorer ${ }^{6}$. And now we see what really can be described as an explosion of obesity and diabetes and associated disorders in children and in early life, not just in rich countries but in most countries, especially in cities. Is this pandemic our 'great warning sign against which the progress of civilisations can be judged', in the resonant words of Rudolf Virchow? ?. Is this a defining time, such as that which inspired John Snow to remove the Broad Street pump?

I rather think it is. It also seems to me that the current mode of thinking - that the solution to problems of public health, including nutrition, lies mainly in improved information for and education of individuals - must be wrong. This approach will no more stop the obesity pandemic than notices in The Times and pamphlets distributed to the huddled masses of London would have stopped the Golden Square cholera outbreak of 1854.

A remarkable new 'alternative world health report' produced by the global network of citizen action groups, the People's Health Movement ${ }^{8}$, summarises compelling evidence that we are living in a world which, from the public health perspective, has gone wrong. Thomas Pogge of the Australian National University commends the book. Commenting on the state of water, sanitation, health-care and food systems that affect the half of the world's population that now live in poverty, and the consequence that over 10 million children die every year from diseases readily preventable by basic public health measures, he says that this is 'the greatest moral outrage of our time'.

It is hard to argue with this judgement. I believe we can't sit back and say all this is nothing to do with us as professionals. We are involved, and directly so with public health nutrition. So what are we doing wrong?

\section{The new nutrition}

It is thoughts and concerns like these that led me to participate in the 2005 workshop that produced The Giessen Declaration 9 , of which I am a signatory, and to contribute to the special issue of this journal in which the new nutrition science is advocated ${ }^{10}$. I am sure that the future of our profession and our science is within the 'new nutrition' three-dimensional biological, social and environmental conceptual framework. And as suggested by the spiral motif of the New Nutrition Science project, many of us now are working on new principles and new practice for a science that brings up to date what the pioneers of public health in the 19th century thought, wrote, taught - and also practised and advocated.

In the rest of this editorial I would like to propose some ways forward. What I propose is not comprehensive, and perhaps some of my colleagues will feel I am being over-cautious $^{11}$; but I do think that as a profession we do need to walk (all right, briskly) before we run ahead of ourselves.

The links between scientific research, discussion, assessment and judgement, the relationship of such processes to government, industry, other professional groups and civil society, and how these all come together, is crucial. I think that getting this right is our major challenge in the next few years. We have touched on such issues in this journal and I hope that the journal will increasingly act as the forum for discussion and resolution of the way forward.

All this said, I believe that in the public interest we need to:

- Agree a suitable evidence-based approach.

- Develop and stick to a logical framework for decisionmaking.

- Act professionally.

\section{Suitable evidence basis}

Decisions and actions in public policy, including public health nutrition, should be rational. This means that an evidence-based approach should be standard in all decision-making, whether this be about industry making health claims or advice on what are healthy diets.

Now that modern research is readily available online, to me this means complete and systematic reviews of all available evidence. This also means an integrated approach using all types of relevant evidence, not just from randomised controlled trials, and not just from studies that fit one's predisposition. Crucially this further means taking account of study quality ${ }^{12}$. Any decisionmaking process that does not start with this approach is likely to be flawed. It should be mandatory as a basis for rational approaches to, for example, proposals to justify novel foods, food fortification, or technological developments liable to change the nature, quality or balance of food supplies.

Currently though, as indicated in a previous editorial, we have a big problem of who calls the research shots ${ }^{13}$. Thus, a recent review in the British Medical Journal has shown that of 289 frequently cited articles in the Web of Science database between 1994 and 2003, 18 out of the 32 most cited trials published after 1999 were funded by industry alone ${ }^{14}$. The authors expressed concern about the impact of industry funding on the type of research undertaken. They concluded: 'Medical research should reflect public needs more closely and the efforts of all of those involved (mainly government, industry and academia) should be better co-ordinated ${ }^{14}$.

This raises the further issue of what types of evidence are most valuable in reviews and assessments designed to 
inform public policy decisions. The early enthusiasm for randomised controlled trials as having any kind of preeminent value is now fading: indeed, by their nature, RCTs, the best method yet devised to test the efficacy of drugs, are often not appropriate in the study of causation, let alone as sources of evidence on which recommendations for policy action can be based.

So how do we move from evidence to action? How do we judge what should be done, for the greater good? And with decisions that affect public health nutrition, locally, nationally and globally, what is the proper role of nutrition scientists?

Boyd Swinburn and colleagues have proposed a broad framework for translating evidence into action, based on their own review of existing evidence-based fameworks ${ }^{15}$. This broadens the evidence base to include issues of context, relevance, feasibility and sustainability. They argue that the types of evidence that should be considered include:

- Observational.

- Experimental.

- Extrapolated.

- Experience.

\section{A logical framework for decicisons}

This new framework has been developed specifically to address the prevention of obesity, and it has a wider use. It helps identify more rational and potentially fruitful ways in which institutions could admit and weigh evidence as a basis for policy action.

They conclude by identifying key features for translating evidence into action:

- The definition of what constitutes evidence needs to be broad and tailored to the question being addressed.

- Assumptions and decisions within the policy development process need to be explicit and transparent.

- Stakeholders need to be involved at each level.

And in general, there is need for a more comprehensive approach in deciding on what actions and interventions to take, and the explicit application of stakeholder judgement in the development of interventions. This allows for actions that may not initially be obvious, such as building the skills of people involved and designing and enhancing structures and systems required to deliver interventions.

\section{Action professionally}

All this said, I am concerned by the apparent lack of leadership and professionalism in our profession.

Here is an example of the challenges that we are not facing. In its consultation document on Television Advertising of Food Drink Products to Children, the Office of Communication (Ofcom) said that the social health benefits of restricting advertising of high-fat, salt and surgery food (HFSS) up to 9 pm could be up to $£ 900$ million per year, while the loss to revenue for broadcasters would be up to $\$ 290$ million per year. Yet Ofcom concluded: 'The exclusion of HFSS advertising before 9 pm would not meet Ofcom's regulatory objectives, and that it is therefore not appropriate to proceed with this option $^{16}$. So Ofcom considered that industry profit was more important than health!

So what does it mean: to act professionally, as we all should? To me this means always thinking, working and acting in what we sincerely believe are the wider interests of society. In turn this means that we should communicate to the public and to policy-makers in a responsible way, and not merely promote our own research or that of colleagues and peers whose results coincide with ours.

I believe, too, that we should oblige ourselves to ask the 'so what?' or 'what for?' questions as we apply for research grants and conduct our work, and that we should think continually of how our work could benefit public health now and in future. To me professional integrity includes not being swayed by current fashion and ideology. Thus, contrary to current neo-liberal ideas, if we believe on the basis of evidence that legal and fiscal interventions will be most effective in the protection and improvement of public health, we should say so, and take the heat.

I also believe that as professionals we have a duty to come together and discuss some of the issues that we know are most important and also disturbing to us as a profession. We do have some elephants in our room. An earlier editorial this year ventilated the issue of fraud in nutrition science ${ }^{13}$.

And there are other issues that we now urgently need to discuss and hopefully agree among ourselves in professional forums. If we do not, we will be rightly seen as 'mere' academics, more interested in the craik of argument than in our professional responsibility to come to collective consensus on matters that vitally concern public health.

One example here is the relative adequacy of methods of dietary assessment. This superficially dry topic has, as we know, immense implications for the judgement of the findings of research science and for public health nutrition recommendations. Is dietary fat, in the quantities consumed in rich countries, a significant cause of breast cancer or not? Is relatively high consumption of fruit and vegetables protective against cancer or not, or not much? We had better make up our minds. And if the answer yes or no depends on the relative weight we give to foodfrequency questionnaires or to more thorough methods of dietary assessment ${ }^{17,18}$, then we had better have these arguments out in professional settings and come to consensus.

This specific issue has very properly been the keynote theme of an international congress held in Copenhagen ${ }^{19}$. But what is the result? A nice debate and continued papers whose titles include polite question marks, in academic 
journals? Or an agreement among us as professionals on which approach has the most merit, and a further agreement that if those of us with the less convincing view make misleading claims about the superiority of their opinions, they will face public censure from their peers?

To me such tough decisions go to the root of the matter. They mark the difference between being an academic and being a professional. And if we really want to make a difference for the better in the world, we had better not act as if our research grants are train sets and realise that we are entrusted with funds in the public interest.

So how can we act collectively as professionals, and effectively express collective views? This is also an issue we need to confront. Indeed, I can't help feeling that my successor as editor-in-chief may need to consider whether, in some crucial themes, Public Health Nutrition as a journal should come off the fence and advocate what its editors believe to be right. I admit that when this thought first occurred to me it felt radical. But in logic I cannot advocate that as a profession we take a line on key issues and at the same time imply that this journal should never come to judgement.

Right now the IUNS, which remains underfunded and has been more a collection of academics than a professional body, seems to be the only game in our global village. Can IUNS, with the support of journals such as this one, gear up so as to become the representative body that speaks with an independent and authoritative voice on the great issues of public health nutrition?

And so as to be able to do this with evident independence, can congress associated with IUNS wrestle free from the coils of their sponsors from the transnational food and drink industry? Other professional bodies in other fields have got tough and have succeeded in the task of gaining the trust and respect of governments, other professions, industry and civil society. As a profession do we want to be independent and to be so seen, and therefore be able to be effective? It is worth a best shot.

Barrie Margetts

Editor-in Chief

\section{References}

1 Carvel J. Childhood obesity has doubled in a decade. The Guardian, 22 April 2006.
2 Miller M, Wetterstrom W. The beginnings of agriculture: the ancient Near East and North Africa [Volume 2, Part 5, Chapter A]. In: Kiple K, Ornelas K, eds. The Cambridge World History of Food. Cambridge: University Press, 2000.

3 McMichael A. Adapting to diversity: climate, food and infection [Chapter 3]. Human Frontiers, Environments and Disease. Past Patterns, Uncertain Futures. Cambridge: University Press, 2001.

4 McMichael A. Infectious disease: humans and microbes coevolving [Chapter 4]. Human Frontiers, Environments and Disease. Past Patterns, Uncertain Futures. Cambridge: University Press, 2001.

5 United Nations Development Programme; Kaul I, Grunberg I, Stern M, eds. Global Public Goods. International Cooperation in the 21st Century. Oxford: University Press, 1999.

6 Garrett L. Betrayal of Trust. The Collapse of Global Public Health. New York: Hyperion, 2000.

7 Ackerknecht E. Rudolf Virchow-Doctor, Statesman, Anthropologist. Madison, WI: University of Wisconsin Press, 1953.

8 Global Health Watch 2005-2006. An Alternative World Health Report. London: Zed Books, 2006.

9 The Giessen Declaration. Public Health Nutrition 2005; 8(6A): 783-6.

10 Vorster HH, Margetts BM, Venter CS, Wissing MP. Integrated nutrition science: from theory to practice in South Africa. Public Health Nutrition 2005; 8(6A): 760-5.

11 Cannon G. Dear friends and colleagues, let's get real [Letter to the Editor]. Public Health Nutrition 2006; 9(4): 531.

12 Margetts BM, Vorster HH, Venter CS. Evidence-based nutrition-review of epidemiological studies. South African Journal of Clinical Nutrition 2002; 15: 68-73.

13 Margetts BM. Stopping the rot in nutrition science [Editorial]. Public Health Nurtition 2006; 9(2): 169-173.

14 Patsopoulos NA, Loannidis JP, Analatos AA. Origin and funding of the most frequently cited papers in medicine: database analysis. British Medical Journal 2006; 332(7549): 1061-4.

15 Swinburn B, Gill T, Kumanyika S. Obesity prevention: a proposed framework for translatin evidence into action. Obesity Reviews 2005; 6(1): 23-33.

16 Office of Communication. Television Advertising of Food and Drink Products to Children: Options for New Restrictions. A Consultation [online], published 28 March 2006. Available at http://www.ofcom.org.uk/consult/condocs/foodads/

17 Bingham S, Luben R, Welch A, Wareham N, Khaw K-T, Day N. Are imprecise methods obscuring a relationship between fat and breast cancer? Lancet 2003; 382(9379): 212-4.

18 Kristal A, Peters U, Potter J. Is it time to abandon the food frequency questionnaire? [Editorial]. Cancer Epidemiology, Biomarkers \& Prevention 2005; 14(12): 2026-8.

19 Sixth International Conference on Dietary Assessment Methods, Cophenhagen, 27-29 April 2006. Homepage: http://www.icdam6.dk 